\title{
Utilization of Bag-Log Waste for Mixture Cultivation of Ear Mushroom (Auricularia auricula) and White Oyster (Pleorotus ostreatus)
}

\author{
Agus Sugianto $^{1, *}$, Anis Sholihah $^{1}$, Abd. Kodir Djaelani ${ }^{2}$, Priyagung Hartono ${ }^{3}$ \\ ${ }^{I}$ Department of Agrotechnology, Faculty of Agriculture, Malang Islamic University, Malang, Indonesia \\ ${ }^{2}$ Department of Management, Faculty of Economics and Business, Malang Islamic University, Malang Indonesia \\ ${ }^{3}$ Department of Mechanical, Faculty of Agineering, Malang Islamic University, Malang, Indonesia \\ *Corresponding author. Email: ags.unisma@yahoo.com
}

\begin{abstract}
The aim of this research was to determine the growth and production of white oyster mushrooms and ear mushrooms on various types of substrates as well as the $\mathrm{R} / \mathrm{C}$ value of farming ratios. Research has been carried out in the Integrated Laboratory of the Faculty of Agriculture, Unisma of Malang. The study was conducted from September 2017 to January 2018. The research design used the factorial completely randomized design (CRD) with two factors. The factor I, kinds of planting substrate (N) consisting of 4 types, N0 (control), N1 (15\% waste powder substrate mixture), N2 (30\% waste powder substrate mixture), N3 (45\% waste powder substrate mixture). Factor II, F1: White oyster mushrooms, and F2: Ear mushrooms. The conclusions obtained show white oyster mushrooms have the best fresh fruit body weight, with a total weight of $564.4 \mathrm{~g}$ per log, significantly different from the ear mushroom which only has a total fresh weight of 242,7 $\mathrm{g}$ fruit body. The white oyster mushroom type has the best BE value with a percentage of $47 \%$, significantly different from the type of ear mushroom which has an BE value with a percentage of $20.3 \%$. The value of $\mathrm{R} / \mathrm{C}$ ratio in the substrate treatment without the rejected mixture on white oyster mushrooms in the value of $\mathrm{R} / \mathrm{C}$ ratio of 1.9 .
\end{abstract}

Keywords: white oyster mushroom, ear mushroom, bag-log waste, substrate variety, $R / C$ ratio

\section{INTRODUCTION}

Oyster mushroom and ear mushroom is one of the most popular mushrooms on the market today as a food ingredient. However, these mushrooms are very difficult to find in nature today and their appearance is also small. Along with the increasing number of business actors/businesses that plunge, indirectly also raises new problems from the oyster mushroom cultivation waste, especially oyster mushroom backlog waste that has expired. It seems that there are recurring problems regarding waste, even though mushroom cultivation actually utilizes sawdust waste but after the waste is utilized new waste appears again $[1,14]$.

Mushroom cultivation waste (baglog) in addition to environmental impact, also affects the mushroom cultivation itself. Wild fungi that often grow in baglog waste mounds as a source of contaminants that cause the failure of mushroom cultivation. Contaminants produce billions of spores, if carried by the wind or through clothing and limbs of workers, are ready to cross all corners of the space including the inoculation chamber of the fungus, mold waste can also cause unpleasant odors if exposed to water and cause air pollution.
Baglog mushroom waste containing $\mathrm{Ca}$ and $\mathrm{P}$ is quite high, this is because in the process of making compost coupled with lime $(\mathrm{CaCO} 3)$ [2,3] the benefits obtained from the use of mushroom growing media waste is the occurrence of reduced production costs due to new sawdust data reduce it by replacing baglog mushroom waste and can also reduce environmental pollution.

\begin{abstract}
Variation of substrate mixture is intended to improve the production of white oyster mushroom (Pleorotus ostreatus) and ear mushroom (Auricularia auricula) by increasing its biological value (EB). Biological efficiency (EB) shows how much the ability of fungi to utilize nutrients in the planting substrate into fruit bodies. The higher the nutrients in the planting substrate are converted into fruit bodies, the higher the results obtained. The higher the value of biological efficiency (EB), the higher the yield obtained $[4,5]$.
\end{abstract}

The aim of this research was to determine the growth and production of white oyster mushrooms and ear mushrooms on various types of substrates as well as the $\mathrm{R} / \mathrm{C}$ value of farming ratios. 


\section{METHODS}

The research was conducted at Faculty of Agriculture Integrated Laboratory and Central Laboratory of Islamic University of Malang, from February to October 2017. The research site is located at an altitude of 500 meters above sea level, with an average daily temperature of $22^{\circ} \mathrm{C}-25^{\circ} \mathrm{C}$. Air humidity $79 \%-86 \%$. The study was conducted in August 2017 to January 2018. The making of the media was carried out four times with different comparisons of new sawdust and reject powders used according to factor one in the comparison of planting media. The research design used factorial completely randomized design (CRD) with two factors. Factor I, kinds of planting substrate $(\mathrm{N})$ consisting of 4 types, N0 (control), N1 (15\% waste powder substrate mixture), N2 ( $30 \%$ waste powder substrate mixture), N3 (45\% waste powder substrate mixture). Factor II, F1: White oyster mushrooms, and F2: Ear mushrooms.

Spawns used in this study using two methods namely DEP (Direct Eksplan Planting). The production of white oyster mushroom spawns by DEP method was made by explants taken from the stem and put into a bottle filled with sterilized corn kernels using autoclave at $121^{\circ} \mathrm{C}$, pressure $15 \mathrm{Lbs}$ for 15 minutes. Substrate that has been inoculated then incubated in dark space with room temperature 27$28^{\circ} \mathrm{C}$ until the mycelium meet the media and ready to be lowered in the next generation $[6,7]$

The data obtained were analyzed using ANOVA test and in the F table test $\alpha=0.05$. If the F test shows the effect of the treatment, then proceed with the Tukey test at $5 \%$ level to compare the treatments.

\section{RESULTS AND DISCUSSION}

\section{The average number of fruit bodies}

Table 1. Average Number of Fruit Bodies in the First Harvest In the Treatment of White Oyster Mushroom and Ear Mushroom Types of Substrate Mixtures

\begin{tabular}{|c|c|}
\hline Treatment & Average \\
\hline N0F1 & $9.4 \mathrm{~b}$ \\
\hline N0F2 & $4.0 \mathrm{a}$ \\
\hline N1F1 & $8.0 \mathrm{~b}$ \\
\hline N1F2 & $4.0 \mathrm{a}$ \\
\hline N2F1 & $7.4 \mathrm{~b}$ \\
\hline N2F2 & $4.2 \mathrm{a}$ \\
\hline N3F1 & $3.2 \mathrm{a}$ \\
\hline N3F2 & $3.2 \mathrm{a}$ \\
\hline Tukey 5\% & $\mathbf{3 . 1 0}$ \\
\hline
\end{tabular}

Note: Numbers marked with the same letter do not show any significant difference in the $5 \%$ Tukey test on observations every week.
The results of the analysis of variance in the observation of the average number of fruit bodies showed an interaction between the treatment of mushroom types and different types of substrate mixtures. The average number of fruit bodies is presented in Table 1.

Mentioned that the ear mushroom fruit body consists of a cap (cap), which is red to black, of medium size with a diameter of $5-20 \mathrm{~cm}$, growing overlapping, soft and not easy to rot [8]. The width of the oyster mushroom body hood has a smaller yield, presumably the influence of a large number of hoods o that there is competition between fruit bodies that cause the fruit hood can not develop properly.

\section{Total Fresh Weight of Fruit Body (TFWFB)}

Figure 1. Shows data on the results of a variety of analysis on the total fresh weight of the fruit body, there is a real interaction between the treatment of mushroom species and the types of substrate mixture types. NOF1 white oyster mushroom has the best fresh fruit body weight, with a total weight of $564.4 \mathrm{~g}$ per $\log$, significantly different from the ear mushroom N1F2 which only has a total fresh body weight of $245.5 \mathrm{~g}$.

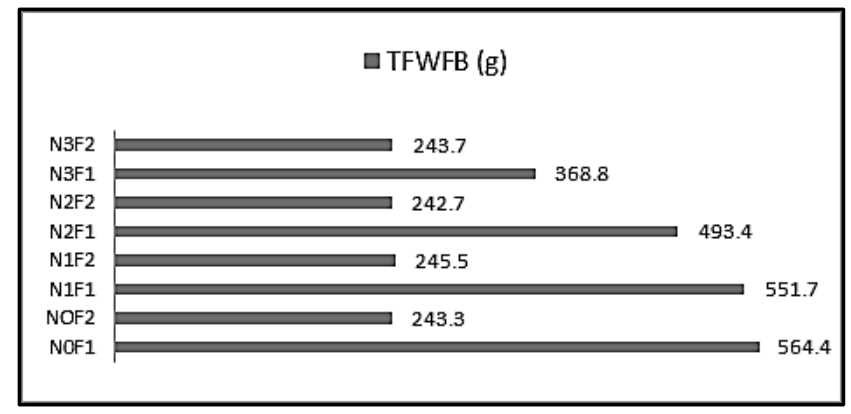

Figure 1. Total Fresh Weight of Fruit Bodies in the First Harvest In the Treatment of White Oyster Mushroom and Ear Mushroom Types of Substrate Mixtures

As stated by [9], the composition of the media greatly influences the growth of oyster mushrooms, due to their nutritional content. Meanwhile, a study conducted by [8], obtained the highest fresh weight of ear fungus at harvest time produced by Auricularia sp-11 grown on a substrate that was given NPK supplement 15-15-15 a concentration of $0.1 \mathrm{~g} / \mathrm{l} \quad(827 \mathrm{~g} / \mathrm{kg}$ wet substrate $)$ or Multitonic PPC 0.1 $\mathrm{ml} / 1(899.87 \mathrm{~g} / \mathrm{kg}$ wet substrate, and from Auricularia sp12 with beef broth supplement application $(872.33 \mathrm{~g} / \mathrm{kg}$ wet substrate).

\section{Biological Efficiency (BE)}

The results of the analysis of variance showed that there was an interaction between the treatment of of white oyster mushroom and ear mushroom types of substrate mixtures on biological efficiency (BE), as shown in figure 2. 


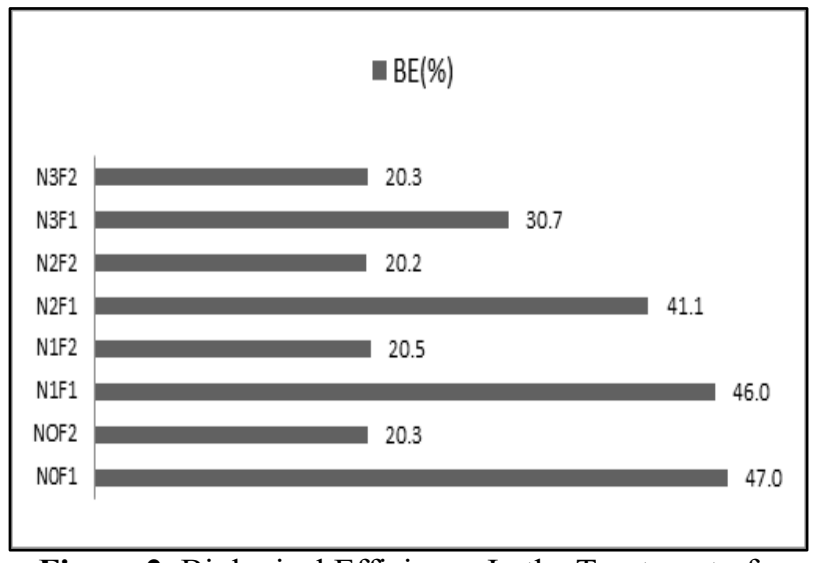

Figure 2. Biological Efficiency In the Treatment of White Oyster Mushroom and Ear Mushroom Types of Substrate Mixtures

Biological efficiency values indicate the ability of fungi to utilize nutrients in the planting substrate into fruit bodies. The value of biological efficiency gives the sense that in the substrate of mushroom planting, how much can be converted into fruit bodies. The high value of biological efficiency shows that from the planting substrate material that has been successfully converted into a high fruit body $[10,11]$.

These low EB values affect the condition of the kombong room which has an average temperature of $26-30^{\circ} \mathrm{C}$, with this high temperature causing humidity in the low kombong room, so that the fruit body growth becomes not optimal. The BE value itself is obtained from the fresh weight of the harvest toral divided by the weight of the initial substrate and multiplied by $100 \%$. The N0F1 treatment showed the highest value of $47 \%$ which was not significantly different from N1F1, meaning that the $15 \%$ baglog mushroom waste mixture was possible to be recommended to farmers $[5,12]$.

\section{Analysis of $R / C$ ratio}

The $\mathrm{R} / \mathrm{C}$ ratio of white oyster mushroom and ear mushroom cultivation in each substrate weight treatment (calculated for 100 baglog) is presented in table 2.

Table 2, shows that in the NOF1 treatment (substrate without a mixture of rejected to white oyster mushrooms) get the highest $\mathrm{R} / \mathrm{C}$ ratio of 1.9 , which means that the treatment has the highest benefit with the profit of each capital of $\mathrm{Rp} 1.00$ will return to $\mathrm{Rp} 1.9$, whereas in the $\mathrm{N} 2 \mathrm{~F} 2$ treatment (substrate with a mixture of over $15 \%$ in the type of ear fungus) has an $\mathrm{R} / \mathrm{C}$ ratio with a value of 1 , which means that means the initial capital of the business with the same income capital, which means it has no profit and also does no harm. In the treatment N3F2 (substrate with a mixture of $45 \%$ reject on the type of ear fungus) has the lowest $\mathrm{R} / \mathrm{C}$ ratio of 0.9 , which means that this treatment does not produce profits.
Operating income can be measured using the analysis of revenue and costs ( $\mathrm{R} / \mathrm{C}$ ratio) suggested in financial calculations. This analysis shows the amount of business revenue the entrepreneur will get for each capital (rupiah) cost incurred for business activities [13].

Table 2. R/C Ratio of cultivation of white oyster mushrooms and ear mushrooms with different weights

\begin{tabular}{|c|c|c|c|}
\hline Treatment & $\begin{array}{c}\text { Acceptance } \\
\text { of farming } \\
\text { (Rp) }\end{array}$ & $\begin{array}{c}\text { Cost of } \\
\text { production } \\
\text { (Rp) }\end{array}$ & $\begin{array}{c}\text { R/C } \\
\text { Ratio }\end{array}$ \\
\hline N0F1 & $1,521,069.00$ & 815,500 & 1.9 \\
\hline N0F2 & $1,008,684.00$ & 817,500 & 1.2 \\
\hline N1F1 & $1,382,567.40$ & 797,500 & 1.7 \\
\hline N1F2 & $858,618.00$ & 799,500 & 1.1 \\
\hline N2F1 & $1,220,601.00$ & 777,500 & 1.6 \\
\hline N2F2 & $754,686.00$ & 779,500 & 1.0 \\
\hline N3F1 & $1,025,002.00$ & 759,500 & 1.3 \\
\hline N3F2 & $699,030.00$ & 761,500 & 0.9 \\
\hline
\end{tabular}

\section{CONCLUSION}

The conclusions obtained show NOF1 white oyster mushrooms have the best fresh fruit body weight, with a total weight of $564.4 \mathrm{~g}$ per $\log$, significantly different from the N2F2 ear mushroom which only has a total fresh weight of 242,7 $\mathrm{g}$ fruit body. white oyster mushroom type NOF1 has the best BE value with a percentage of $47 \%$, significantly different from the type of ear mushroom $\mathrm{N} 2 \mathrm{~F} 2$ which has an BE value with a percentage of $20.3 \%$. The value of $\mathrm{R} / \mathrm{C}$ ratio in the substrate treatment without the rejected mixture on white oyster mushrooms in the value of $\mathrm{R} / \mathrm{C}$ ratio of 1.9 .

Total body weight and biological efficiency of white oyster mushrooms growing on media without an rejected mixture have the highest yield, but do not differ greatly with additional media rejects $15 \%$, while the ear fungus is also the best result in the media without the rejected mixture, but it does not differ greatly with the mixture of the estimated $15 \%$ and $30 \%$. rejected, but not much different, so that it can be used as a mixture of $15 \%$ of new sawdust to minimize usual expenses.

\section{ACKNOWLEDGMENT}

The first author thanks the Directorate General for Higher Education of the Ministry of National Education of Indonesia (RISTEKDIKTI; Leading Research of Higher Education, 2018) for financial support throughout this researched. Mushroom house and laboratory facilities provided by the Faculty of Agriculture of Malang Islamic University. 


\section{REFERENCES}

[1] S. Maryati, 2009. "Laporan MagangBudidaya Jamur Kuping (Auriculariaauriculajudae(Linn.) Schroter)". UPTD.Balai Pengembangan dan PromosiTanaman Pangan Hortikultura.Surakarta.

[2] A. Sugianto, A. 2017. "Pengembangan Teknologi Jamur Edibel Sebagai Pangan Alternatif'. Intimedia Publishing. Malang. Indonesia. ISBN. 978-602-1507-37-7.

[3] Suharnowo, 2012. "Pertumbuhan Miselium dan Badan Buah Jamur Tiram Putih" Jurnal Lantera Bio.1(3): 12-17.

[4] S.U. Purnomowati, 2015. "Biologi Jamur Kuping (Auricularia auricula)". Makalah Penyuluhan Jamur Pangan di Desa Argo Peni Kabupaten Kebumen.

[5] A. Sugianto, A. 2007. Pengujian Bibit Jamur Tiram Putih yaqng di buat dengan Metode Cold Shock Methods dan Biakan Murni Miselium". J. Agritek 15(6): 1512-1517.

[6] R. Maulidina, Murdiono, W. E., and Nawawi, M. 2015. "Pengaruh Pertumbuhan Bibit dan Komposisi Media Tanam Terhadap Pertumbuhan dan Hasil jamur Tiram Putih (Pleoratus ostreatus)". Jurnal Produksi Tanaman, 3 (8), 649-657.

[7] S. Hafifi. 2013. "Uji Efektifitas dan Efisiensi Metode Tanam Eksplan Langsung (TEL) Sebagai inovasi Pembibitan Jamur Tiram Putih (Pleurotus ostreatus)". J. Agronisma. 1(1): 5-10.

[8] Sumiati. 2005. Repair of White Oyster Mushroom Pleurotus ostreatus Florida Strain with Modification of Main Raw Materials Substrate. J. Hort 16(2).
[9] H.O. Stanley HO, Odu NN. 2012. "Cultivation Of Oyster Mushroom (Pleurotus Tuber-Regium) On Selected Organic Waste", .International Journal of Advance Biological Research 2: 446448.

[10] A. Sugianto, A., A.1 Solihah, and P. Hartono. 2017. "Acceleration of Five Types Edibel Wood Mushroom Production through Varied Harvest Synchronization Temperature Settings". Journal of Agriculture and Environmental Sciences. 6(2):128-133.

[11] Tracy E. Tisdale Susan C. Miyasaka. Don E. Hemmes. 2006. "Cultivation of the oyster mushroom (Pleurotus ostreatus) on wood substrates in Hawaii".World Journal of Microbiology and Biotechnology. 22(3):201.

[12] T. Tisdale, E. Susan, C. And Miyasaka-Hemmes, D.E. 2006. "Cultivation Of The Oyster Mushroom (Pleurotus ostreatus) On Wood Substrates In Hawai. World”. J. Microbiol.Biotechnol. (22) 201-20.

[13] Y. Zhang, Geng, W., Shen, Y., Wang, Y., \& Dai, Y. 2014. "Edible mushroom cultivation for food security and rural development in China": bio-innovation, technological dissemination and marketing. Sustainability. 2(6): 2961-2973.

[14] M.Z. Rosmiza, Davies, WP, Rosniza Aznie CR, Jabil MJ, and Mazdi M. 2016. Prospects for Increasing Commercial Mushroom Production in Malaysia: Challenges and Opportunities. Mediterranean Journal of Social Sciences.MCSER Publishing, Rome-Italy. 7(1): 406-415. 